\title{
Does being a refugee affect prognosis in patients who underwent surgery due to peptic ulcer perforation?
}

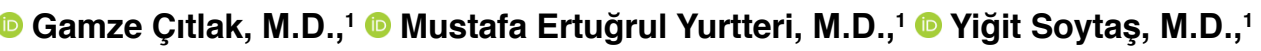

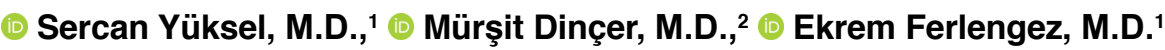

\begin{abstract}
${ }^{1}$ University of Health Sciences, Haseki Training and Research Hospital, Department of General Surgery, İstanbul-Turkey
${ }^{2}$ Department of General Surgery, Fırat University Faculty of Medicine, Elazığ-Turkey
\end{abstract}

\begin{abstract}
BACKGROUND: Although Turkey hosts the largest number of Syrian immigrants, the interpretation of their health problems seems to be inadequate and understudied. In this study, we aimed to investigate whether being a refugee is a prognostic factor or not for peptic ulcer perforation (PUP).

METHODS: A retrospective study was designed in Turkish Citizen patients and the refugees to compare the prognosis who underwent surgery for PUP. After ethical committee approval, the data of 143 patients, constituting I 30 males and I 3 females, operated for PUP, were collected. Patients' files, surgery notes and outpatient policlinic data were evaluated.

RESULTS: In this study, 105 patients were Turkish Citizen, while the remaining 38 patients were refugees. Eight (7.6\%) Turkish and one (2.6\%) refugee patient died. There was no statistical significance between the two groups concerning mortality $(p=0.445)$. Age, perforation diameter and localization, need of reoperation, nasogastric tube detention time, CRP, hematocrit, albumin, creatinine, BUN levels were found statistically significant for mortality.
\end{abstract}

CONCLUSION: Although being a refugee has been identified as a risk in the etiopathogenesis of peptic ulcer disease, we found that being a refugee in Turkey is not a negative prognostic factor for PUP.

Keywords: Morbidity; mortality; peptic ulcer perforation; refugee.

\section{INTRODUCTION}

Peptic ulcer disease refers to an insult to the mucosa of the upper digestive tract resulting in ulceration that extends beyond the mucosa and into the submucosal layers. Peptic ulcers disease most commonly occur in the stomach and duodenum. While most of peptic ulcers are initially asymptomatic, clinical manifestations range from mild dyspepsia to complications, including gastrointestinal system bleeding, perforation, and gastric outlet obstruction. ${ }^{[1]}$

Peptic ulcer perforation (PUP) had a high mortality rate before the 1950s. However, nowadays, the mortality rate is decreased due to some factors like technological progress in medicine and easy reach to the health service. Patients experiencing ulcer perforation usually have a peptic ulcer disease or gastritis history, and most of them have also used proton pump inhibitors (PPI).

PUP is known as a young smoker disease. Mainly stress, young age, smoking, usage of some medicines like non-steroidal anti-inflammatory drugs (NSAIDs) and helicobacter pylori infections have been accused in etiology.

PUP is a common surgical emergency worldwide, with mortality rates up to $30 \%$. PUP is the most common cause of emergency surgery among the complications of the gastroduodenal ulcers. Morbidity and mortality in PUP occur due

Cite this article as: Çıtlak G, Yurtteri ME, Soytaş Y, Yüksel S, Dinçer M, Ferlengez E. Does being a refugee affect prognosis in patients who underwent surgery due to peptic ulcer perforation? Ulus Travma Acil Cerrahi Derg 2020;26:713-718.

Address for correspondence: Yiğit Soytaş, M.D.

Sağlık Bilimleri Üniversitesi, Haseki Eğitim ve Araştırma Hastanesi, Genel Cerrahi Kliniği, İstanbul, Turkey

Tel: +90 212 - 5294400 E-mail: yigitsoytas@hotmail.com

Ulus Travma Acil Cerrahi Derg 2020;26(5):7I3-718 DOI: 10.14744/tjtes.2020.44902 Submitted: 0I.10.2019 Accepted: 13.06.2020 Online: I5.09.2020

Copyright 2020 Turkish Association of Trauma and Emergency Surgery 
to secondary peritonitis and sepsis. Helicobacter pylori and the use of NSAIDs are common causes. Due to the differences between countries in age, sex, localization of perforation and underlying causes, mortality rates also vary. Early surgery, either by laparoscopic or open repair and proper sepsis management is essential for a good outcome. Selected patients can be managed non-operatively or with novel endoscopic approaches. $^{[2,3]}$

Since 201I, the conflict in Syria has led to the migration of over five million refugees to Turkey and this number seems to be increased in the future. Only $6.1 \%$ of the Syrian refugees live in temporary shelters. ${ }^{[4]}$ Most of them also have a problem because there is a minimal similarity between Turkish and Arabic languages. Also, some of these refugees are fugitive and have no registration to the Turkish State and Health System. Being homeless and unemployment usually lead to a poor environment concerning health. Due to the factors listed above, it is possible that refugees in Turkey admit to the hospital later than Turkish citizens do. Because of this condition, we thought that being a refugee could have been a prognostic factor for PUP.

\section{MATERIALS AND METHODS}

This retrospective clinical trial was conducted at the University of Health Sciences Haseki Training and Research Hospital. Clinical Ethical Committee approval was received from the University of Health Sciences Haseki Training and Research Hospital (18.10.2017-533). The patients who were diagnosed and treated by the General Surgery Department for PUP between January 2014 and January 2017 were included in this study. The patients were evaluated in two groups constituting of Turkish citizen and refugee patients.

In addition to clinical examination, the diagnosis was established by the help of biochemical laboratory findings, such as leucocyte count, c reactive protein (CRP) blood plasma level, plasma amylase, hematocrit $(\mathrm{Htc})$ level, creatinine, albumin, blood urea nitrogen (BUN) values, and radiological techniques like posterior-anterior chest and abdominal X-ray and if necessary computed tomography were used as imaging modalities.

Patients' sex, age, nation, PUP localization, perforation diameter, operation techniques (open Graham patch, laparoscopic Graham patch and others), duration of hospital stay, duration of nasogastric tube usage, oral nutrition starting time, need of re-operation, complications and mortality were recorded. All data were analyzed by SPSS 15.0 for Windows. Descriptive statistics were carried out, and a comparison of two groups was made by the Mann-Whitney $U$ and Chi-square tests for comparisons of numerical variables that do not provide a normal distribution. Predictive factors were examined by logistic regression analysis. The statistical significance level was considered as $\mathrm{p}<0.05$.

\section{RESULTS}

The mean age was $40.0 \pm 17.6$ (15-93) years. The total number of PUP patients was 143. Most of these patients were men $(n=130)$. While $105(73.4 \%)$ were Turkish citizen, and $38(26.6 \%)$ were refugees. Pre-pyloric, post-pyloric and other sites, such as antrum, were the localizations of the perforations in 78 (54.5\%), 62 (43.4\%) and 3 (2l\%) patients, respectively. Mean duration of hospital stay was $6.8 \pm 3.4(I-2 I)$ days. Six (4.2\%) of the patients had reoperation because of complications like evisceration and intraabdominal abscess. A pneumoperitoneum image on an abdominal X-ray was present in 42 (29.4\%) patients. Also, 128 of patients had posterior-anterior chest X-ray and $64(44.8 \%)$ of all patients had a pneumoperitoneum image on chest $X$-ray 95 of patients had an abdominal computed tomography (CT) and 76 (53.5\%) of all patients had a pneumoperitoneum image on CT. Mortality rate was $6.3 \%(n=9)$ (Table I).

Abdominal X-ray assessment revealed statistical significance, because pneumoperitoneum presence at abdominal X-ray was $50 \%(n=19)$ in Turkish and $21.9 \%(n=23)$ in refugee patients $(p=0.13)$. There was no statistical significance between mortality and the nation (Table 2).

Age, perforation diameter, reoperation and complication rates were statistically significantly higher in mortal patients ( $p<0.001, p<0.001, p=0.003, p<0,001$, respectively). The mortality rate of patients with other types of surgery was higher than Graham patch surgery. In laboratory evaluations, CRP, creatinine, BUN, amylase values were significantly high, whereas Htc and albumin values were statistically significantly low (Table 3).

For the factors determining mortality, the number of days of nasogastric tube usage, post-pyloric localization and perforation diameter were the most significant factors in the model consisting of variables $p<0.250$ in the Single Variable analysis for logistic regression $(p=0.003, p=0.038, p=0.001$, respectively) (Table 4). There were no statistically significant differences in biochemical evaluations between the two groups.

\section{DISCUSSION}

PUP is more common in men than in women, and it is the most common form of a benign reason for acute abdomen, which needs emergency surgery after counted than acute appendicitis, creating a major health issue. Changes in living standards and medical usage, such as steroids, stress and smoking, contribute to perforation formation.

Several studies have demonstrated that Helicobacter pylori infection increases PUP rates. PPI may be used daily in routine by patients for chronic gastritis. The previous studies showed no increased risk of PUP by the increased age. Also, it is reported that the length of smoking and usage of NSAIDs increases the risk of PUP. ${ }^{[5-7]}$ 
Table I. Demographic, biochemical and radiological findings of the groups

\begin{tabular}{|c|c|c|}
\hline & $\mathbf{n}$ & $\%$ \\
\hline \multicolumn{3}{|l|}{ Sex } \\
\hline Male & 130 & 90.9 \\
\hline Female & 13 & 9.1 \\
\hline Age, Mean $\pm S D$ & \multicolumn{2}{|c|}{$40.0 \pm 17.6(15-93)$} \\
\hline \multicolumn{3}{|l|}{ Nation } \\
\hline Turkish & 105 & 73.4 \\
\hline Others & 38 & 26.6 \\
\hline \multicolumn{3}{|l|}{ Localization } \\
\hline Pre-pyloric & 78 & 54.5 \\
\hline Post-pyloric & 62 & 43.4 \\
\hline Other (e.g., Antrum) & 3 & 2.1 \\
\hline Perforation diameter $(\mathrm{mm})$ & \multicolumn{2}{|c|}{$7.6 \pm 5.9(2-30)$} \\
\hline \multicolumn{3}{|l|}{ Operation } \\
\hline Graham Patch & 123 & 86.0 \\
\hline \multicolumn{3}{|l|}{ Technique } \\
\hline Laparoscopic Graham Patch & 10 & 7.0 \\
\hline Other (e.g., Antrectomy) & 10 & 7.0 \\
\hline Duration of hospital stay & \multicolumn{2}{|c|}{$6.8 \pm 3.4(I-2 I)$} \\
\hline Starting time of oral nutrition & \multicolumn{2}{|c|}{$4.0 \pm 1.8(2-18)$} \\
\hline Nasogastric tube usage day & \multicolumn{2}{|c|}{$3.6 \pm 2.5(1-18)$} \\
\hline \multicolumn{3}{|l|}{ Re-operation } \\
\hline No & 137 & 95.8 \\
\hline Yes & 6 & 4.2 \\
\hline \multicolumn{3}{|l|}{ Complication } \\
\hline No & 122 & 85.3 \\
\hline Yes & 21 & 14.7 \\
\hline Leucocytes & \multicolumn{2}{|c|}{$14.9 \pm 7.3(3.47-75)$} \\
\hline C-reactive protein & \multicolumn{2}{|c|}{$55.7 \pm 97.8(0.18-500)$} \\
\hline Hematocrit & \multicolumn{2}{|c|}{$42.0 \pm 6.6(15.9-62)$} \\
\hline Albumin & \multicolumn{2}{|c|}{$3.87 \pm 0.78(1.23-5.4)$} \\
\hline Creatinine & \multicolumn{2}{|c|}{$0.97 \pm 0.83(0.21-8.79)$} \\
\hline Blood urea nitrogen & \multicolumn{2}{|c|}{$40.0 \pm 29.4(15.8-234)$} \\
\hline Amylase & \multicolumn{2}{|c|}{$81.4 \pm 69.5(21-731)$} \\
\hline \multicolumn{3}{|l|}{ Abdominal } \\
\hline \multicolumn{3}{|l|}{ Direct X-Ray } \\
\hline None & 21 & 14.7 \\
\hline Pneumoperitoneum & 42 & 29.4 \\
\hline Air-liquid level & 5 & 3.5 \\
\hline Normal & 75 & 52.4 \\
\hline Chest X-Ray & & \\
\hline None & 12 & 8.4 \\
\hline Pneumoperitoneum & 64 & 44.8 \\
\hline Normal & 66 & 46.2 \\
\hline Computed tomography & & \\
\hline None & 47 & 33.1 \\
\hline Pneumoperitoneum & 76 & 53.5 \\
\hline Free liquid & 8 & 5.6 \\
\hline Contrast extralumination & 6 & 4.2 \\
\hline Normal & 5 & 3.5 \\
\hline Mortality & & \\
\hline No & 134 & 93.7 \\
\hline Yes & 9 & 6.3 \\
\hline
\end{tabular}

Table 2. Comparison of the features patients' nations

\begin{tabular}{|c|c|c|c|c|c|}
\hline & \multicolumn{4}{|c|}{ Nation } & \multirow[t]{3}{*}{$\mathbf{p}$} \\
\hline & \multicolumn{2}{|c|}{ Turkish } & \multicolumn{2}{|c|}{ Others } & \\
\hline & $\mathbf{n}$ & $\%$ & $\mathbf{n}$ & $\%$ & \\
\hline \multicolumn{6}{|l|}{ Re-operation } \\
\hline No & 100 & 95.2 & 37 & 97.4 & 1.000 \\
\hline Yes & 5 & 4.8 & I & 2.6 & \\
\hline \multicolumn{6}{|l|}{ Complication } \\
\hline No & 89 & 84.8 & 33 & 86.8 & 0.756 \\
\hline Yes & 16 & 15.2 & 5 & 13.2 & \\
\hline \multicolumn{6}{|l|}{ Abdominal } \\
\hline \multicolumn{6}{|l|}{ Direct x-ray } \\
\hline None & 17 & 16.2 & 4 & 10.5 & \\
\hline Pneumoperitoneum & 23 & 21.9 & 19 & 50.0 & 0.013 \\
\hline Air-liquid level & 4 & 3.8 & I & 2.6 & \\
\hline Normal & 61 & 58.1 & 14 & 36.8 & \\
\hline \multicolumn{6}{|l|}{ PALX } \\
\hline None & 10 & 9.5 & 2 & 5.3 & 0.183 \\
\hline Pneumoperitoneum & 42 & 40.0 & 22 & 57.9 & \\
\hline Normal & 53 & 50.5 & 14 & 36.8 & \\
\hline \multicolumn{6}{|l|}{$\mathrm{CT}$} \\
\hline None & 33 & 31.7 & 14 & 36.8 & 0.331 \\
\hline Pneumoperitoneum & 53 & 51.0 & 23 & 60.5 & \\
\hline Free liquid & 7 & 6.7 & I & 2.6 & \\
\hline Contrast extralumination & 6 & 5.8 & 0 & 0.0 & \\
\hline Normal & 5 & 4.8 & 0 & 0.0 & \\
\hline \multicolumn{6}{|l|}{ Mortality } \\
\hline No & 97 & 92.4 & 37 & 97.4 & 0.445 \\
\hline Yes & 8 & 7.6 & 1 & 2.6 & \\
\hline
\end{tabular}

Kanno et al. ${ }^{[5]}$ found that 87 (27\%) of 329 peptic ulcers emerged from refugee shelters, and the majority (76 of 87 ) of them was the bleeding type. Multivariate regression showed that residence in a shelter was a strong risk factor for ulcer bleeding, independent of the progressiveness of ulcer diseases. Accommodation in a refugee shelter can be a strong risk factor for ulcer bleeding after a large-scale disaster since acid-suppressive drugs are supposed to decrease the risk for stress-induced ulcer bleeding. Although the trial was above actually related to ulcer bleeding risks, it shows us indirectly the PUP rate can be increased in the refugee population, too. Despite that opinion in our trial, we found that there was no statistical significance between refugees and Turkish citizens.

There had been several reports about the increase of peptic ulcers under a large-scale from disaster to war. It was still unclear that severe psychological stress itself caused peptic ulcer independently of two major causes, which are Helico- 
Table 3. A multivariate analyses for mortality

\begin{tabular}{|c|c|c|c|c|c|c|c|c|}
\hline & & \multicolumn{6}{|c|}{ Mortality } & \multirow[t]{3}{*}{$\mathbf{p}$} \\
\hline & & \multicolumn{3}{|c|}{ No } & \multicolumn{3}{|r|}{ Yes } & \\
\hline & & $\mathbf{n}$ & $\%$ & Mean $\pm S D$ & $\mathbf{n}$ & $\%$ & Mean $\pm S D$ & \\
\hline \multirow[t]{2}{*}{ Sex } & Male & 122 & 91.0 & & 8 & 88.9 & & 0.587 \\
\hline & Female & 12 & 9.0 & & 1 & II.I & & \\
\hline Age & & & & $38.1 \pm 15.9(35)$ & & & $69.3 \pm 17.2(70)$ & $<0.001$ \\
\hline \multirow[t]{2}{*}{ Nation } & Turkish & 97 & 72.4 & & 8 & 88.9 & & 0.445 \\
\hline & Others & 37 & 27.6 & & 1 & II.I & & \\
\hline \multirow[t]{3}{*}{ Localization } & Pre-pyloric & 76 & 56.7 & & 2 & 22.2 & & 0.151 \\
\hline & Post-pyloric & 55 & 41.0 & & 7 & 77.8 & & \\
\hline & Others & 3 & 2.2 & & 0 & 0.0 & & \\
\hline Perforation(mm) & & & & $6.8 \pm 4.6(5)$ & & & $19.3 \pm 9.4(20)$ & $<0.001$ \\
\hline \multirow[t]{3}{*}{ Operation } & Graham Patch & 118 & 88.1 & & 5 & 55.6 & & 0.003 \\
\hline & Lap Graham Patch & 10 & 7.5 & & 0 & 0.0 & & \\
\hline & Other (e.g., Antrectomy) & 6 & 4.5 & & 4 & 44.4 & & \\
\hline Duration of hospital stay & & & & $6.7 \pm 3.2(6)$ & & & $8.4 \pm 5.9(10)$ & 0.621 \\
\hline Starting of oral nutrition & & & & $4.0 \pm 1.9(4)$ & & & $3.9 \pm 0.4(4)$ & 0.587 \\
\hline Nasogastric tube duration & & & & $3.4 \pm 1.9(3)$ & & & $7.7 \pm 6.1(5)$ & 0.085 \\
\hline \multirow[t]{2}{*}{ Re-operation } & No & $13 \mid$ & 97.8 & & 6 & 66.7 & & 0.003 \\
\hline & Yes & 3 & 2.2 & & 3 & 33.3 & & \\
\hline \multirow[t]{2}{*}{ Complication } & No & 119 & 88.8 & & 3 & 33.3 & & $<0.001$ \\
\hline & Yes & 15 & 11.2 & & 6 & 66.7 & & \\
\hline Leucocytes & & & & $14.7 \pm 7.4(13.9)$ & & & $16.6 \pm 6.2(15.7)$ & 0.287 \\
\hline C-reactive protein & & & & $50.8 \pm 94.9(8.7)$ & & & $128.2 \pm \mid 17.6(\mid 10.4)$ & 0.021 \\
\hline Hematocrit & & & & $42.3 \pm 6.1(42.7)$ & & & $37.6 \pm 11.4(38.3)$ & 0.026 \\
\hline Albumin & & & & $3.98 \pm 0.67(4.2)$ & & & $2.29 \pm 0.70(2.11)$ & $<0.001$ \\
\hline Creatinine & & & & $0.92 \pm 0.8 \mathrm{I}(0.8)$ & & & $1.73 \pm 0.88(1.57)$ & $<0.001$ \\
\hline Blood urea nitrogen & & & & $37.1 \pm 26.4(32)$ & & & $83.8 \pm 38.4(97)$ & $<0.001$ \\
\hline Amylase & & & & $78.3 \pm 67.4(65.8)$ & & & $128.5 \pm 87.3(115)$ & 0.099 \\
\hline \multicolumn{9}{|l|}{ Abdominal direct } \\
\hline \multirow[t]{4}{*}{ X-ray } & None & 19 & 14.2 & & 2 & 22.2 & & 0.065 \\
\hline & Pneumoperitoneum & 42 & 31.3 & & 0 & 0.0 & & \\
\hline & Air-liquid level & 4 & 3.0 & & 1 & II.I & & \\
\hline & Normal & 69 & 51.5 & & 6 & 66.7 & & \\
\hline \multirow[t]{3}{*}{ Chest X-Ray } & None & II & 8.2 & & I & II.I & & 0.343 \\
\hline & Pneumoperitoneum & 62 & 46.3 & & 2 & 22.2 & & \\
\hline & Normal & 61 & 45.5 & & 6 & 66.7 & & \\
\hline \multirow[t]{5}{*}{ Computed tomography } & None & 46 & 34.3 & & $\mathrm{I}$ & 12.5 & & 0.014 \\
\hline & Pneumoperitoneum & 73 & 54.5 & & 3 & 37.5 & & \\
\hline & Free liquid & 6 & 4.5 & & 2 & 25.0 & & \\
\hline & Contrast extralumination & 4 & 3.0 & & 2 & 25.0 & & \\
\hline & Normal & 5 & 3.7 & & 0 & 0.0 & & \\
\hline
\end{tabular}

bacter pylori infection and nonsteroidal anti-inflammatory drug. Disaster (psychological) stress possibly induces peptic ulcer independently of two major causes described above. Moreover, people living in a refugee shelter immediately af- 
Table 4. Logistic regression analysis for factors determining mortality

\begin{tabular}{|c|c|c|c|c|c|}
\hline & & $\mathbf{p}$ & OR & $95 \% \mathrm{Cl}$ & \\
\hline \multirow[t]{10}{*}{ Enter Model } & Age & 0.392 & 1.031 & 0.961 & 1.106 \\
\hline & Localization pre-pyloric & 0.292 & & & \\
\hline & Post-pyloric & 0.117 & 9.327 & 0.573 & 151.846 \\
\hline & Other (e.g., Antrectomy) & 0.999 & 0.000 & 0.000 & . \\
\hline & Perforation (mm) & 0.027 & 1.268 & 1.027 & 1.565 \\
\hline & Operation Graham Patch & 0.324 & & & \\
\hline & Laparoscopic Graham patch & 0.999 & 0.000 & 0.000 & . \\
\hline & Other (e.g., Antrectomy) & 0.133 & 7.002 & 0.552 & 88.868 \\
\hline & Nasogastric tube duration & 0.020 & 1.361 & 1.050 & 1.764 \\
\hline & Nation (Others) & 0.569 & 2.290 & 0.132 & 39.637 \\
\hline \multirow[t]{5}{*}{ Backward Model } & Localization pre-pyloric & 0.117 & & & \\
\hline & Post-pyloric & 0.038 & 19.218 & 1.171 & 315.289 \\
\hline & Other (e.g., Antrectomy) & 0.999 & 0.000 & 0.000 & . \\
\hline & Perforation (mm) & 0.001 & 1.312 & 1.120 & 1.536 \\
\hline & Nasogastric tube duration & 0.003 & 1.436 & 1.132 & 1.823 \\
\hline
\end{tabular}

ter a disaster are a strong risk group of peptic ulcer bleeding. ${ }^{[5]}$

Carlsson et al. ${ }^{[8]}$ also found that war is a reason for post-traumatic stress disease and some of the outcomes were symptoms of depression and anxiety. We also know that anxiety and depression may cause peptic ulcer disease and its complications.

In Dovjak et al.'s ${ }^{[7]}$ trial, they found that the mortality in elderly patients over the age of 80 years with peptic ulcers in the case of complications, such as bleeding and perforation, is higher than the general population. In our trial, we also found that mortality increases with the age of patients. Duodenal ulcers are associated with Helicobacter pylori infections in $90 \%$ of cases and in $70 \%$ of gastric ulcers. ${ }^{[7]}$

In Varcus et al.'s ${ }^{[3]}$ trial and review, there were 32 studies included, counting 3488 patients with Laparoscopic patch and 5208 with Graham patch. LPR patients had shorter hospital stays. They also emphasized the increased mortality rate in Graham patch patients because of their tendency to be more shocked or with higher ASA at presentation. In our series, there was no difference concerning mortality.

In Mohsina et al.'s ${ }^{[9]}$ clinical trial, they evaluated the feasibility and efficacy of ERAS pathways in patients undergoing emergency simple closure of perforated duodenal ulcer. In this trial, patients with refractory shock, ASA class $\geq 3$, and perforation size $\geq \mathrm{I} \mathrm{cm}$ were excluded. Ninety-nine patients were included and 49 and 50 patients were included in standard care and ERAS group, respectively. The duration of hospital stay in the
ERAS group was significantly shorter. There was a significant reduction in postoperative morbidity, such as postoperative nausea, vomiting and pulmonary complications. This trial shows us early nasogastric tube extraction and starting oral nutrition may reduce the morbidity and mortality rate. This was also a lack of our trial, and that should be surveyed in the future, too.

In our study, patients who underwent laparoscopic Graham patch have no mortality, and it was statistically significant. However, no clinical significance was considered because laparoscopic surgery was performed in appropriate patients. Wang et al. ${ }^{[10]}$ found that there was no significant difference in baseline data between the laparoscopic patch and Graham patch (all $\mathrm{p}>0.05$ ). No significant differences in operation time, the morbidity of postoperative complication, mortality, reoperation probability, nasogastric decompression time, fluid diet recovery time and hospitalization cost were found between two groups (all $\mathrm{p}>0.05$ ).

According to several studies, being a refugee is a risk factor for peptic ulcer disease and its complication; therefore, we decided to investigate whether being a refugee was a prognostic factor for PUP. However, we found there was no difference between refugees and Turkish citizens concerning mortality and morbidity.

In our study, we found a similar prognosis between Turkish patients and refugees. We thought that, as a government policy, uncharged emergency healthcare and easy admission to hospital might be the reason for a similar prognosis between two groups. 
Ethics Committee Approval: Approved by the local ethics committee.

Peer-review: Internally peer-reviewed.

Authorship Contributions: Concept: G.Ç., S.Y., Y.S.; Design: S.Y., Y.S.; Supervision: G.Ç., E.F.; Materials: M.D., M.E.Y., E.F.; Data: M.E.Y., E.F.; Analysis: G.Ç., S.Y., Y.S.; Literature search: M.D., Y.S., M.E.Y.; Writing: G.Ç., S.Y., E.F.; Critical revision: G.Ç., Y.S.

Conflict of Interest: None declared.

Financial Disclosure: The authors declared that this study has received no financial support.

\section{REFERENCES}

1. Stern E, Sugumar K, Journey JD. Peptic Ulcer Perforated. In: StatPearls [Internet]. Treasure Island, FL: StatPearls Publishing; 2020.

2. Søreide K, Thorsen K, Harrison EM, Bingener J, Møller MH, Ohene-Yeboah M, et al. Perforated peptic ulcer. Lancet 2015;386:1288-98. [CrossRef]

3. Varcus F, Paun I, Duta C, Dobrescu A, Frandes M, Tarta C. Laparoscopic repair of perforated peptic ulcer. Minerva Chir 2018;73:188-93.
4. Ergönül Ö, Tülek N, Kayı I, Irmak H, Erdem O, Dara M. Profiling infectious diseases in Turkey after the influx of 3.5 million Syrian refugees. Clin Microbiol Infect 2020;26:307-12. [CrossRef]

5. Kanno T, Iijima K, Koike T, Abe Y, Shimada N, Hoshi T, et al. Accommodation in a refugee shelter as a risk factor for peptic ulcer bleeding after the Great East Japan Earthquake: a case-control study of 329 patients. J Gastroenterol 2015;50:31-40.

6. Kanno T, Iijima K, Koike T, Shimosegawa T. Relationship between disaster stress and peptic ulcers. [Article in Japanese]. Nihon Rinsho 2015;73:1209-14.

7. Dovjak P. Duodenal ulcers, gastric ulcers and Helicobacter pylori. [Article in German]. Z Gerontol Geriatr 2017;50:159-69. [CrossRef]

8. Carlsson J, Sonne C, Vindbjerg E, Mortensen EL. Stress management versus cognitive restructuring in trauma-affected refugees-A pragmatic randomised study. Psychiatry Res 2018;266:116-23. [CrossRef]

9. Mohsina S, Shanmugam D, Sureshkumar S, Kundra P, Mahalakshmy T, Kate V. Adapted ERAS Pathway vs. Standard Care in Patients with Perforated Duodenal Ulcer-a Randomized Controlled Trial. J Gastrointest Surg 2018;22:107-16. [CrossRef]

10. Wang Q, Ge B, Huang Q. A prospective randomized controlled trial of laparoscopic repair versus open repair for perforated peptic ulcers. [Article in Chinese]. Zhonghua Wei Chang Wai Ke Za Zhi 2017;20:300-3.

\section{ORIJINAL ÇALIŞMA - ÖZET}

\section{Peptik ülser perforasyonunun cerrahi tedavisinde mülteci olmak prognozu etkiler mi? Geriye dönük klinik çalışma}

\section{Dr. Gamze Çıtlak, ${ }^{1}$ Dr. Mustafa Ertuğrul Yurtteri,, ${ }^{1}$ Dr. Yiğit Soytaş, ${ }^{1}$ Dr. Sercan Yüksel,, Dr. Mürşit Dinçer, ${ }^{2}$ Dr. Ekrem Ferlengez ${ }^{1}$}

${ }^{1}$ Sağlık Bilimleri Üniversitesi, Haseki Eğitim ve Araştırma Hastanesi, Genel Cerrahi Kliniği, İstanbu ${ }^{2}$ Fırat Üniversitesi Tıp Fakültesi, Genel Cerrahi Anabilim Dalı, Elazığ

AMAÇ: Türkiye çok sayıda Suriyeli göçmene ev sahipliği yapmasına rağmen, sağlık sorunlarının yorumlanması yetersiz ve anlaşılmamış gibi görünmektedir. Mülteci olmanın, peptik ülser perforasyonu (PUP) hastalı̆ı için prognostik bir faktör olup olmadığını araştırmayı amaçladık.

GEREÇ VE YÖNTEM: Türkiye Cumhuriyeti vatandaşı ve mülteci olan hastaların PUP açısından prognozlarını karşılaştırmak için retrospektif bir çalışma tasarlandı. PUP nedeniyle ameliyat edilen 130 erkek ve 13 kadından oluşan 143 hastanın 105'i Türk, geri kalan 38'i mülteci idi. Hastaların dosyaları, ameliyat notları ve poliklinik verileri değerlendirildi.

BULGULAR: Sekiz (\%7.6) Türk vatandaşı ve bir (\%2.6) mülteci hastada mortalite saptandı ve iki grup arasında mortalite açısından istatistiksel bir anlamlılık saptanmadı $(p=0.445)$. Yaş, perforasyon çapı ve lokalizasyonu, reoperasyon ihtiyacı, nazogastrik dekompresyon süresi, $C R P$, hematokrit, albümin, kreatinin, BUN düzeyleri mortalite açısından istatistiksel olarak anlamlı bulundu.

TARTIŞMA: Bir mülteci olmak, peptik ülser hastalığının etiyopatogenezinde bir risk olarak tanımlanmış olmasına rağmen, Türkiye'de mülteci olmanın PUP için negatif bir prognostik faktör olmadığını tespit ettik.

Anahtar sözcükler: Morbidite; mortalite; mülteci; peptik ülser perforasyonu.

Ulus Travma Acil Cerrahi Derg 2020;26(5):7।3-718 doi: 10.14744/tjtes.2020.44902 